\title{
A proprietary herbal extract titred in verbascoside and aucubin suppresses lipopolysaccharide-stimulated expressions of cyclooxygenase- 2 in human neutrophils
}

\author{
GIULIA NANNONI ${ }^{I}$, GIULIA VOLTERRANI ${ }^{1}$, ALESSANDRO MATTAROCCI ${ }^{I}$, \\ ALESSANDRO ALI' $\grave{I}^{\prime}$ MARCO BERTONA ${ }^{2}$, ENZO EMANUELE ${ }^{2}$ \\ ${ }^{1}$ LaBiotre Srl, Tavarnelle Val di Pesa, Florence, Italy \\ ${ }^{2} 2 \mathrm{E}$ Science, Robbio, Pavia, Italy
}

\begin{abstract}
Introduction: Bacterial lipopolysaccharide (LPS) initiates several major cellular responses that play a crucial role in the pathogenesis of inflammation, including activation of neutrophils and production of prostaglandin E2 (PGE2) by cyclooxygenase-2 (COX-2).

Material and methods: Recent years have witnessed a growing interest in natural compounds as promising alternatives to synthetic COX-2 inhibitors. In this study, we sought to investigate the effect of a proprietary herbal extract from Lippia citriodora and Plantago lanceolata, titred in verbascoside $(\geq 5 \%)$ and aucubin $(\geq 2 \%)$, against LPS-stimulated expressions of COX-2 in human neutrophils using both reverse transcription-polymerase chain reaction (RT-PCR) and a PGE2 immunoassay.

Results: Our main results indicated that: 1 . The proprietary herbal extract titred in verbascoside and aucubin is not significantly cytotoxic as shown by the MTT assay; 2. The extract does not significantly inhibit COX-1, whereas it is able to suppress LPS-elicited COX-2 hyperexpression at the mRNA level in human neutrophils; and 3. The effect of the extract at $5 \%$ concentration was comparable to that elicited celecoxib 1\%, although, in terms of absolute and relative reduction of COX-2 mRNA expression and production of PGE2 in human neutrophils, the drug significantly outperformed the extract.

Conclusions: In general, these results suggest that the proprietary herbal extract titred in verbascoside and aucubin is safe and may possess significant anti-inflammatory and analgesic effects by acting as a specific COX-2 inhibitor. Further studies are required to confirm the clinical efficacy of the extract.
\end{abstract}

Key words: lipopolysaccharide, neutrophils, cyclooxygenase-2, prostaglandin E2, verbascoside, aucubin.

(Cent Eur J Immunol 2020; 45 (2): 125-129)

\section{Introduction}

Bacterial lipopolysaccharide (LPS) initiates a number of major cellular responses that play a crucial role in the pathogenesis of inflammation, including activation of neutrophils and production of prostaglandin E2 (PGE2), a key pro-inflammatory molecule synthesized from arachidonic acid by cyclooxygenase (COX) $[1,2]$. There are two isoforms of the cyclooxygenase enzyme, i.e., cyclooxygenase-1 (COX-1) and cyclooxygenase-2 (COX-2) [3]. $\mathrm{COX}-1$ is a constitutively expressed molecule in different physiologic conditions (including protection of gastric mucosa and platelet hemostasis), whereas COX-2 is markedly upregulated upon inflammatory stimuli (in turn, inducing the production of large PGE2 amounts) [4]. Human neutrophils play a crucial role in COX-2 hyperexpression during inflammatory responses [5]. Although these mechanisms are essentially defensive, the prolonged or excessive activation of COX-2 in neutrophils can result in significant pain and swelling, such as that occurring in musculoskeletal inflammation and arthritis [6]. Consequently, COX2 inhibition is an important drug target for counteracting inflammation and pain perception [7].

Non-selective non-steroidal anti-inflammatory drugs (NSAIDs) that inhibit the activity of both COX-1 and COX-2 have become the mainstay of treatment for a va-

Correspondence: Dr Enzo Emanuele, 2E Science, Via Monte Grappa 13, I-27038 Robbio, Pavia, Italy,

e-mail: enzo.emanuele@2escience.com

Submitted: 24.04.2019; Accepted: 11.07.2019 
riety of inflammatory conditions [8]. However, traditional NSAIDs are characterized by numerous potential adverse effects, including gastrointestinal bleeding, cardiovascular side effects, and NSAID-induced nephrotoxicity [8]. To overcome these issues, the use of selective COX-2 inhibitors (coxibs), which offer the advantage of an anti-inflammatory, anti-pyretic, and analgesic activity similar to that of non-selective inhibitor NSAIDs with little or none of their known adverse effects, has gained momentum [9, 10].

Recent years have witnessed a growing interest in natural compounds as promising alternatives to synthetic COX-2 inhibitors $[11,12]$. Verbascoside, a natural polyphenol known for its high antioxidant power, has been previously shown to reduce the expression and activity of inducible pro-inflammatory genes in the human histiocytic lymphoma cell line U937 [13]. Aucubin, a naturally occurring iridoid glycoside, has been reported to attenuate tumor necrosis factor- $\alpha$-induced inflammatory responses [14]. Moreover, it can reverse elevated gene and protein expression of several pro-inflammatory molecules, including $\mathrm{COX}-2$, following an interleukin- $1 \beta$ challenge in rat chondrocytes [15].

Because COX-2 is an inducible enzyme and is critically involved in inflammation, we sought to investigate the effect of a proprietary herbal extract from Lippia citriodo$r a$ and Plantago lanceolata, titred in verbascoside $(\geq 5 \%)$ and aucubin $(\geq 2 \%)$, against LPS-stimulated expressions of COX-2 in human neutrophils using both reverse transcription-polymerase chain reaction (RT-PCR) and a PGE2 immunoassay. The rationale behind the potential inhibitory activity against COX-2 of this specific extract from two plant species was as follows. First, there is in vitro evidence that verboscoside can effectively inhibit COX-2 $[13,16]$. Second, extracts from Plantago lanceolata have been reported to exert anti-inflammatory effects in a murine macrophage cell line [17] and to inhibit COX-2 in a murine model of carrageenan-induced paw edema [18].

\section{Material and methods}

\section{Isolation of neutrophils}

Human neutrophils were isolated from whole blood samples collected from 10 healthy volunteers ( 5 males and 5 females; mean age, $34.1 \pm 3.7$ years) using EasySep direct human neutrophil isolation kit (STEMCELL Technologies, Vancouver, Canada). After isolation, neutrophils were resuspended at a concentration of $5 \times 10^{6}$ cells $/ \mathrm{ml}$ in Hank's balanced salt solution $\left(37^{\circ} \mathrm{C}\right)$, containing $10 \mathrm{mM}$ HEPES pH 7.4, $1.6 \mathrm{mM} \mathrm{Ca}^{2+}$, and no $\mathrm{Mg}^{2+}$.

\section{Materials}

LPS was purchased from InvivoGen (Toulouse, France). The proprietary herbal extract (VERBAScox ${ }^{\circledR}$ ) titred in verbascoside $(\geq 5 \%)$ and aucubin $(\geq 2 \%)$ was obtained from
LaBiotre S.r.l. (Tavarnelle Val di Pesa, Italy). Celecoloxib (a known pharmacological inhibitor of COX-2) was purchased from Sigma-Aldrich (St. Louis, MO, USA).

\section{Cell viability}

Cell viability was determined using MTT assay kit (Promega, Madison, WI, USA) according to the manufacturer's instruction. In order to determine the cytotoxicity of the proprietary extract, cells were incubated with aqueous solutions of the verbascoside/aucubin extract at three different concentrations $(1 \%, 3 \%$, and $5 \%)$ for 24 hours. Cultures of the control group were left untreated and their viability was set at $100 \%$. For comparison purposes, cells were also treated for 24 hours with $1 \%$ celecoxib solution, which was prepared as previously described [19]. After incubation, ten microliters of MTT labeling reagent were added to each well. After 4 hours, a 100- $\mu$ l aliquot of solubilization solution was added, followed by 12 hours of incubation. Absorbance was subsequently measured with a microtiter plate reader (Bio-Tek, Winooski, VT, USA) at a test wavelength of $595 \mathrm{~nm}$ and a reference wavelength of $690 \mathrm{~nm}$. Optical density (OD) was calculated as the difference between the absorbance at the reference wavelength and that at the test wavelength. Percent viability was calculated using the following formula: (OD of the treated sample/control OD) $\times 100$.

\section{Incubations with LPS at different experimental conditions}

Experiments were conducted in RPMI medium supplemented with $1 \%$ fetal bovine serum $\left(37^{\circ} \mathrm{C}, 5 \% \mathrm{CO}_{2}, 95 \%\right.$ humidity), after seeding neutrophils $\left(5 \times 10^{5}\right.$ cells/well $)$ in a 96 -well plate. Table 1 summarizes the six different experimental conditions tested in the study.

\section{Expression analysis of COX-1 and COX-2 mRNA}

To identify expressions of COX-1 and COX-2 mRNA, RT-PCR was performed. Total RNA was isolated from neutrophils using RNAzol ${ }^{\mathrm{TM} B}$ (TEL-TEST, Friendswood, TX, USA). Two micrograms of RNA and $2 \mu$ of random hexamers (Promega) were added together, and the mixture was heated at $65^{\circ} \mathrm{C}$ for 10 minutes. One microliter of AMV reverse transcriptase (Promega), $5 \mu \mathrm{l}$ of $10 \mathrm{mM}$ $\mathrm{dNTP}$ (Promega), $1 \mu \mathrm{l}$ of RNasin (Promega), and $5 \mu \mathrm{l}$ of $10 \times$ AMV RT buffer (Promega) were then added to the mixture. The final volume was brought up to $50 \mu \mathrm{l}$ with diethyl pyrocarbonate-treated water, and the reaction mixture was then incubated at $42^{\circ} \mathrm{C}$ for 1 hour. PCR amplification was performed in a reaction volume of $40 \mu \mathrm{l}$ containing $1 \mu \mathrm{l}$ of the appropriate cDNA, $1 \mu \mathrm{l}$ of each set of primers at a concentration of $10 \mathrm{pM}, 4 \mu \mathrm{l}$ of $10 \times \mathrm{RT}$ buffer, $1 \mu \mathrm{l}$ of $2.5 \mathrm{mM}$ dNTP, and 2 units of Taq DNA polymerase (Promega). The primers sequence for human $\mathrm{COX}-1$ were as follows: forward: 5'- CGCCAGTGAATCCCTGTTGTT-3' 
and reverse 5'-AAGGTGGCATTGACAAACTCC-3'. The primer sequence for human COX-2 included: forward: 5'-CTGGCGCTCAGCCATACAG-3' and reverse 5'-CGCACTTATACTGGTCAAATCCC-3'. The primers sequence for glyceraldehyde 3-phosphate dehydrogenase (GAPDH; housekeeping gene) were as follows: forward 5'-GGAGCGAGATCCCTCCAAAAT-3' and reverse 5'-GGCTGTTGTCATACTTCTCATGG-3'. PCR amplifications were carried out using GeneAmp 9600 PCR system (Perkin Elmer, Norwalk, CT, USA) in subsequent conditions: initial denaturation at $94^{\circ} \mathrm{C}$ for 5 minutes, followed by 40 cycles, each consisting of denaturation at $94^{\circ} \mathrm{C}$ for 30 seconds, annealing at $58^{\circ} \mathrm{C}$ for 30 seconds, and extension at $72^{\circ} \mathrm{C}$ for 30 seconds, with a final extension step at the end of the procedure at $72^{\circ} \mathrm{C}$ for 5 minutes. The amounts of RT-PCR products for each of the mRNA species at the six different experimental conditions outlined above were calculated densitometrically using Molecular Analyst ${ }^{\mathrm{TM}}$ software (Bio-Rad, Hercules, CA, USA). Experiments were conducted in triplicate, and quantitative gene expression data were normalized to the expression levels of GAPDH.

\section{Assessment of PGE2 concentrations}

Assessment of PGE2 concentrations in each well in the six different experimental conditions was performed using a commercially available PGE2 competitive enzyme immunoassay kit (GE Healthcare, Milwaukee, WI, USA). All experiments were performed in triplicate.

\section{Data analysis}

Statistical calculations were performed using GraphPad 7.0 (GraphPad Inc., San Diego, CA, USA). Results were expressed as the means \pm standard deviations. Data were analyzed by one-way ANOVA, followed by post-hoc Dunn's tests. A two-tailed $p$-value $<0.05$ was considered statistically significant.

\section{Results}

\section{Cell viability}

Based on the results of MTT assay, the viabilities of cells incubated for 24 hours with the verbascoside/aucubin extract solubilized at $1 \%, 3 \%$, and $5 \%$ concentrations were $91 \pm 3 \%, 87 \pm 5 \%$, and $81 \pm 7 \%$ of the control value $(100 \%)$ observed in untreated cells. The cell viability of cells incubated with celecoxib $1 \%$ was $90 \pm 2 \%$. Altogether, the results of MTT assay revealed that the verbascoside/aucubin extract exerted no major cytotoxicity in human neutrophils.

\section{COX-1 and COX-2 expression analysis by RT-PCR}

RT-PCR analysis of mRNA levels of COX-1 and COX-2 was performed in order to provide an estimate of the relative levels of expressions of these genes in the
Table 1. Experimental conditions used in the study

\begin{tabular}{cl}
\hline Condition & \multicolumn{1}{c}{ Protocol } \\
\hline 1 & Untreated cells (control) \\
\hline 2 & Cells exposed to $5 \mu \mathrm{g} / \mathrm{ml}$ LPS for $24 \mathrm{~h}$ \\
\hline 3 & $\begin{array}{l}\text { Cells exposed to } 5 \mu \mathrm{g} / \mathrm{ml} \text { LPS plus verbascoside/ } \\
\text { aucubin extract in } 1 \% \text { solution for } 24 \mathrm{~h}\end{array}$ \\
\hline 4 & $\begin{array}{l}\text { Cells exposed to } 5 \mu \mathrm{g} / \mathrm{ml} \text { LPS plus verbascoside/ } \\
\text { aucubin extract in } 3 \% \text { solution for } 24 \mathrm{~h}\end{array}$ \\
\hline 5 & $\begin{array}{l}\text { Cells exposed to } 5 \mu \mathrm{g} / \mathrm{ml} \text { LPS plus verbascoside/ } \\
\text { aucubin extract in } 5 \% \text { solution for } 24 \mathrm{~h}\end{array}$ \\
\hline 6 & $\begin{array}{l}\text { Cells exposed to } 5 \mu \mathrm{g} / \mathrm{ml} \mathrm{LPS} \mathrm{plus} \mathrm{celecoxib} \mathrm{in} 1 \% \\
\text { solution for } 24 \mathrm{~h}\end{array}$ \\
\hline
\end{tabular}

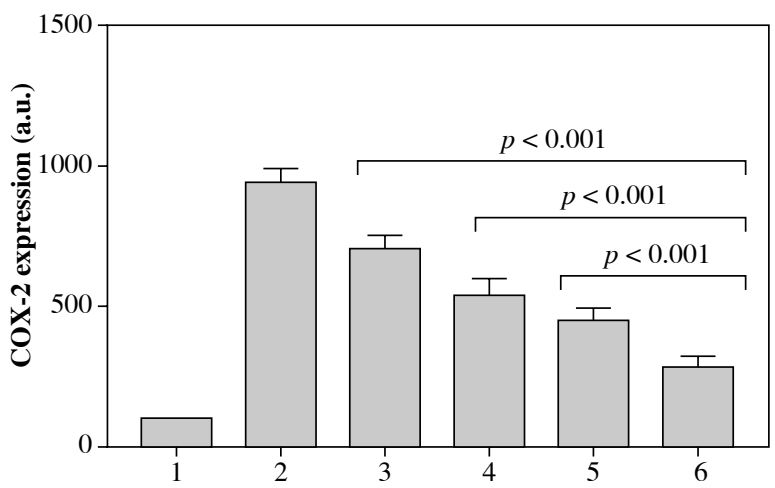

Fig. 1. Quantitative expression of COX-2 mRNA measured in the six different experimental conditions reported in Table 1. Experiments were conducted in triplicate, and quantitative gene expression data were normalized to the expression levels of GAPDH. All $p$ values $<0.001$ for conditions $3,4,5$, and 6 vs. condition $2 ; p$ value $<0.001$ for condition 6 vs. conditions 3,4 , and 5

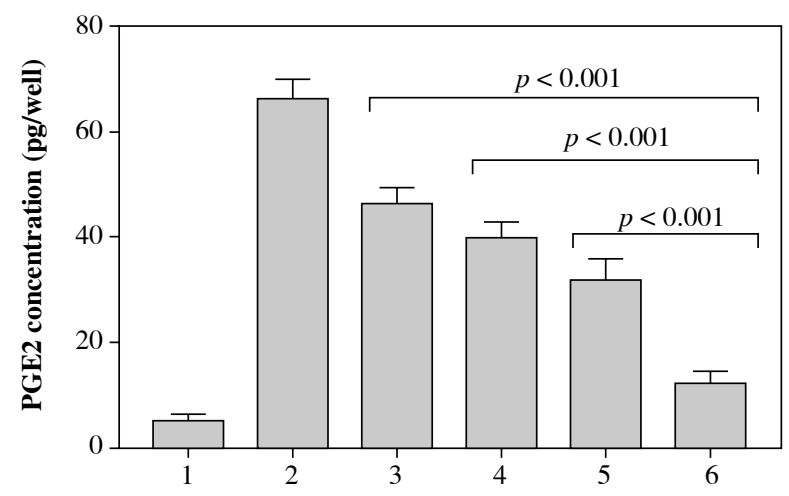

Fig. 2. PGE2 concentrations measured in the six different experimental conditions reported in Table 1 . All $p$ values $<0.001$ for conditions $3,4,5$, and 6 vs. condition $2 ; p$ value $<0.001$ for condition 6 vs. conditions 3,4 , and 5 
six different experimental conditions outlined above. The mRNA levels of COX-1 and COX-2 in untreated cells were used as the control value and set at 100 arbitrary units (a.u.). After treatment with $5 \mu \mathrm{g} / \mathrm{ml}$ LPS for 24 hours, the expression of COX-1 was $108 \pm 10$ a.u. The levels of COX-1 mRNA, following the exposure to $5 \mu \mathrm{g} / \mathrm{ml} \mathrm{LPS}$ plus verbascoside/aucubin extract at $1 \%, 3 \%$, and $5 \%$ concentrations for 24 hours were $111 \pm 8,96 \pm 11$, and $91 \pm 9$ a.u., respectively. Expression levels of cells exposed to $5 \mu \mathrm{g} / \mathrm{ml}$ LPS plus celecoxib at $1 \%$ for 24 hours were $116 \pm 4$ a.u. All these changes were not statistically significant, suggesting that treatments did not influence COX-1 expression.

The level of COX-2 mRNA after the treatment with $5 \mu \mathrm{g} / \mathrm{ml}$ LPS for 24 hours significantly increased to $971 \pm 49$ a.u. The levels of COX-2 mRNA following the exposure to $5 \mu \mathrm{g} / \mathrm{ml}$ LPS plus verbascoside/aucubin extract at $1 \%, 3 \%$, and $5 \%$ concentrations for 24 hours were $702 \pm 51,536 \pm 63$, and $449 \pm 46$ a.u., respectively (all $p<0.001$ vs. treatment with $5 \mu \mathrm{g} / \mathrm{ml}$ LPS). Expression levels of cells exposed to $5 \mu \mathrm{g} / \mathrm{ml}$ LPS plus celecoxib at $1 \%$ for 24 hours were $283 \pm 37$ a.u. (Fig. $1 ; p<0.001$ vs. verbascoside/aucubin extract at $5 \%$ ).

\section{PGE2 immunoassay}

The results of PGE2 immunoassay revealed that, after 24 hours of exposure to LPS, the amount of PGE2 increased from $5.12 \pm 1.24 \mathrm{pg} /$ well to $66.21 \pm 3.67 \mathrm{pg} / \mathrm{well}$. The levels of PGE2 following the exposure to $5 \mu \mathrm{g} / \mathrm{ml} \mathrm{LPS}$ plus verbascoside/aucubin extract at $1 \%, 3 \%$, and $5 \%$ concentrations for 24 hours were $46.29 \pm 3.10 \mathrm{pg} /$ well, 39.83 $\pm 2.97 \mathrm{pg} / \mathrm{well}$, and $32.11 \pm 3.89 \mathrm{pg} /$ well (all $p<0.001 \mathrm{vs}$. treatment with $5 \mu \mathrm{g} / \mathrm{ml}$ LPS). Concentrations of PGE2 to $5 \mu \mathrm{g} / \mathrm{ml}$ LPS plus celecoxib at $1 \%$ for 24 hours were 19.21 \pm 2.39 pg/well (Fig. $2 ; p<0.001$ vs. verbascoside/aucubin extract at $5 \%$ ).

\section{Discussion}

An increased COX-2 expression leads to an enhanced production of PGE2, which is strongly associated with the onset of inflammation and pain $[8,9]$. The main results of this study are as follows: 1 . The proprietary herbal extract titred in verbascoside $(\geq 5 \%)$ and aucubin $(\geq 2 \%)$ was not significantly cytotoxic as shown by MTT assay; 2 . The extract did not significantly inhibit COX-1, whereas it was able to suppress LPS-elicited COX-2 hyperexpression at the mRNA level in human neutrophils; 3 . In an experimental inflammatory in vitro model, the effect of the extract at $5 \%$ concentration was comparable to that elicited celecoxib $1 \%$, although, in terms of absolute and relative reduction of COX-2 mRNA expression and production of PGE2 in human neutrophils, the drug significantly outperformed the extract. Overall, these results suggest that the proprietary herbal extract titred in verbascoside and aucubin is safe and may exert significant clinical anti-inflammatory and analgesic effects by acting as a specific COX-2 inhibitor. However, further studies are required to confirm the clinical utility of the extract.

Pesce et al. [13] have previously reported that verbascoside inhibited PGE2 synthesis in the activated human histiocytic lymphoma U937 cell line, an effect mediated by COX2 inactivation. Similarly, Esposito et al. [20] demonstrated that verbascoside prevented the activation of COX-2 in glioma cells without simultaneous inhibition of COX-1 enzyme. Our findings confirm and expand these observations by showing that the extract in our study was able to inhibit both COX-2 expression and PGE2 synthesis in a cell type (human neutrophils), which plays a key role in acute inflammation. As far as aucubin is concerned, Park et al. [21] reported that a hydrolyzed-aucubin product was able to exert a moderate inhibition on COX-2 without affecting COX-1 expression. Although subject to future confirmation, it can be speculated that verbascoside and aucubin might exert synergistic effects against COX-2 expression and ultimately, serving as natural coxibs.

\section{Conclusions}

In summary, our current data provided an evidence to understand the anti-inflammatory action of herbal extract titred in verbascoside and aucubin, and indicated a therapeutic potential in various inflammatory diseases, where COX-2 hyperexpression and overproduction of PGE2 have been proven to play a role.

\section{Acknowledgements}

This study was supported by an unrestricted grant from 2E Science, Robbio (PV), Italy.

The authors declare no conflict of interest.

\section{References}

1. Kamachi F, Ban HS, Hirasawa N, et al. (2007): Inhibition of lipopolysaccharide-induced prostaglandin E2 production and inflammation by the $\mathrm{Na}+/ \mathrm{H}+$ exchanger inhibitors. J Pharmacol Exp Ther 321: 345-352.

2. Tang T, Scambler TE, Smallie T, et al. (2017): Macrophage responses to lipopolysaccharide are modulated by a feedback loop involving prostaglandin E2, dual specificity phosphatase 1 and tristetraprolin. Sci Rep 7: 4350.

3. Kulkarni SK, Jain NK, Singh A (2000): Cyclooxygenase isoenzymes and newer therapeutic potential for selective COX-2 inhibitors. Methods Find Exp Clin Pharmacol 22: 291-298.

4. Rouzer CA, Marnett LJ (2009): Cyclooxygenases: structural and functional insights. J Lipid Res 50: S29-34.

5. St-Onge M, Flamand N, Biarc J, et al. (2007): Characterization of prostaglandin E2 generation through the cycloox- 
ygenase (COX)-2 pathway in human neutrophils. Biochim Biophys Acta 1771: 1235-1245.

6. Nagano S, Otsuka T, Niiro H, et al. (2002): Molecular mechanisms of lipopolysaccharide-induced cyclooxygenase-2 expression in human neutrophils: involvement of the mitogen-activated protein kinase pathway and regulation by anti-inflammatory cytokines. Int Immunol 14: 733-740.

7. Everts B, Währborg P, Hedner T (2000): COX-2-specific inhibitors--the emergence of a new class of analgesic and anti-inflammatory drugs. Clin Rheumatol 19: 331-343.

8. Hawkey CJ (2001): COX-1 and COX-2 inhibitors. Best Pract Res Clin Gastroenterol 15: 801-820.

9. Chakraborti AK, Garg SK, Kumar R, et al. (2010): Progress in COX-2 inhibitors: a journey so far. Curr Med Chem 17: 1563-1593.

10. Capone ML, Tacconelli S, Sciulli MG, et al. (2003): Clinical pharmacology of selective COX-2 inhibitors. Int J Immunopathol Pharmacol 16: 49-58.

11. Jachak SM (2006): Cyclooxygenase inhibitory natural products: current status. Curr Med Chem 13: 659-678.

12. Chandel P, Rawal RK, Kaur R (2018): Natural products and their derivatives as cyclooxygenase-2 inhibitors. Future Med Chem 10: 2471-2492.

13. Pesce M, Franceschelli S, Ferrone A, et al. (2015): Verbascoside down-regulates some pro-inflammatory signal transduction pathways by increasing the activity of tyrosine phosphatase SHP-1 in the U937 cell line. J Cell Mol Med 19: 1548-1456.

14. Park KS (2013): Aucubin, a naturally occurring iridoid glycoside inhibits TNF- $\alpha$-induced inflammatory responses through suppression of NF- $\mathrm{KB}$ activation in 3T3-L1 adipocytes. Cytokine 62: 407-412.

15. Wang SN, Xie GP, Qin CH, et al. (2015): Aucubin prevents interleukin-1 beta induced inflammation and cartilage matrix degradation via inhibition of NF- $\mathrm{\kappa B}$ signaling pathway in rat articular chondrocytes. Int Immunopharmacol 24: 408-415.

16. Abdelouahab N, Heard C (2008): Effect of the major glycosides of Harpagophytum procumbens (Devil's Claw) on epidermal cyclooxygenase-2 (COX-2) in vitro. J Nat Prod 71: 746-749.

17. Vigo E, Cepeda A, Gualillo O, Perez-Fernandez R (2005): In-vitro anti-inflammatory activity of Pinus sylvestris and Plantago lanceolata extracts: effect on inducible NOS, COX$1, \mathrm{COX}-2$ and their products in J774A.1 murine macrophages. J Pharm Pharmacol 257: 383-391.

18. Fakhrudin N, Dwi Astuti E, Sulistyawati R, et al. (2017): $\mathrm{n}$-Hexane insoluble fraction of Plantago lanceolata exerts anti-inflammatory activity in mice by inhibiting cyclooxygenase-2 and reducing chemokines levels. Sci Pharm 85: E12.

19. Agrawal S, Soni N, Jain NK, Agrawal GP (2012): Solubility enhancement of poorly water soluble celecoxib for parenteral formulations. Int J Pharm Sci 3: 2325-2336.

20. Esposito E, Dal Toso R, Pressi G, et al. (2010): Protective effect of verbascoside in activated C6 glioma cells: possible molecular mechanisms. Naunyn Schmiedebergs Arch Pharmacol 381: 93-105.

21. Park KS, Kim BH, Chang IM (2010): Inhibitory potencies of several iridoids on cyclooxygenase-1, cyclooxygnase-2 enzymes activities, tumor necrosis factor- $\alpha$ and nitric oxide production in vitro. Evid Based Complement Alternat Med 7: 41-45. 